\title{
Penguatan Ekonomi Rumah Tangga pada Masa Pandemi Covid-19 di Kelurahan Sario Kota Baru Kecamatan Sario Kota Manado
}

\author{
Victorina Tirayoh $^{1 *}$, Diana Lintong ${ }^{2}$ \\ ${ }^{\mathbf{1 , 2}}$ Program Studi Akuntansi, Fakultas Ekonomi dan Bisnis \\ Universitas Sam Ratulangi \\ *Penulis Korespondensi. Email: vtirayoh@unsrat.ac.id
}

\begin{abstract}
ABSTRAK
Kelurahan Sario Kota Baru merupakan salah satu kelurahan yang ada di Kecamatan Sario Kota Manado, yang merupakan lokasi strategis sebagai tempat untuk menjalankan usaha atau berbisnis karena letak yang strategis dekat dengan pusat keramaian dan persekolahan yang termasuk sekolah terfavorit yang ada di Kota Manado yaitu SMA Negeri 1 manado dan SMK Negeri 1 Manado. Pada saat dunia menghadapi situasi pandemi Covid-19 maka terjadi perubahan yang sangat besar dalam seluruh aspek kehidupan masyarakat, termasuk salah satunya larangan untuk berkumpul sehingga segala sesuatunya harus di kerjakan dari rumah. Hal ini sangat berdampak dalam berbagai sektor termasuk bisnis dan usaha yang dijalankan oleh masyarakat yang ada di kelurahan Sario Kota Baru Manado. Diliburkannya sekolah dan pegawai kantor sangat berpengaruh terhadap penghasilan usaha masyarakat yang sebagian besar konsumennya adalah para guru, pegawai dan siswa yang ada. Adapun kelompok masyarakat yang bekerja di perusahaan swasta merasakan hal yang sama akibat adanya pembatasan karyawan sehingga harus menerima keputusan pihak perusahaan untuk dirumahkan sementara. Kegiatan PKM Penguatan Ekonomi Rumah Tangga pada Masa Pandemi Covid-19 di Kelurahan Sario Kota Baru Kecamatan Sario Kota Manado diharapkan membantu masyarakat dalam meningkatkan pendapatan/penghasilan rumah tangga untuk kesejahteraan masyarakat. Metode yang akan dilakukan adalah penyuluhan, pelatihan dan pembagian sembako. Kegiatan ini sudah berlangsung dengan baik, dan masyarakat yang ikut sangat merasakan manfaat dari kegiatan ini terlebih di masa menghadapi pandemi Covid-19.
\end{abstract}

Kata kunci: Penguatan Ekonomi Rumah tangga, Masa Pandemi Covid-19

\begin{abstract}
Sario Kota Baru Subdistrict is one of the sub-districts in Manado City Sario Subdistrict, which is a strategic location as a place to run a business or do business because of its strategic location close to the center of crowds and schools which are among the most favorite schools in Manado City, namely SMA Negeri 1 Manado and SMK Negeri 1 Manado. When the world is facing the Covid-19 pandemic situation, there have been very big changes in all aspects of people's lives, including one of the restrictions on gathering so that everything must be done from home. This has a profound impact on various sectors including businesses and businesses run by the people in the Sario Kota Baru Manado village. The dismissal of schools and office employees greatly affects the income of the community's businesses, most of whose customers are teachers, employees and students. Meanwhile, community groups who work in private companies feel the same way due to employee restrictions so they must accept the company's decision to be temporarily laid off. PKM Activities to Strengthen Household Economics during the Covid-19 Pandemic in Sario Kota Baru Village, Sario District, Manado City are expected to help the community in increasing household income / income for the welfare of the
\end{abstract}


community. The methods to be carried out are counseling, training and distribution of basic necessities. This activity has been going well, and the people who have benefited greatly from this activity, especially in the face of the Covid-19 pandemic.

Keywords: Strengthening the Household Economy, Covid-19 Pandemic Period

\section{PENDAHULUAN \\ Analisis Situasi}

Tidak ada seorangpun di dunia ini yang tahu kapan berakhirnya masa Pandemi Covid19, yang saat ini menjadi masalah utama bagi semua bangsa di dunia, termasuk kita bangsa Indonesia dan yang ada di daerah wilayah Sulawesi Utara. Sejak munculnya virus corona pada akhir tahun 2019 di Kota Wuhan Provinsi Hubei Negara Cina, seluruh dunia mulai gempar dengan adanya virus kecil yang ternyata sangat berbahaya dan dapat membunuh manusia.

Sejak pertama kali virus tersebut terdeteksi pada 2 Maret 2020 dan diumumkan langsung oleh Presiden Joko Widodo, angka kasus wabah virus menunjukkan bahwa paling tidak sampai saat ini, peningkatan terlihat cukup signifikan dan stabil dengan rata-rata 100 kasus per hari. Kurva angka kasus COVID19 pun sama sekali belum menunjukkan kecenderungan menurun. Berbagai sumber, baik dari dalam maupun luar negeri, telah memprediksi angka kasus COVID-19 di Indonesia akan mencapai puluhan bahkan ratusan ribu. Pemerintah berupaya keras untuk menjaga keselamatan dan kesejahteraan rakyatnya dengan melakukan usaha-usaha agar penyebaran virus ini tidak meluas dan memutuskan rantai penyebaran virus ini sehingga tidak akan menyebabkan banyak korban. Himbauan dan ajakan yang terus disosialisasikan antara lain dengan menjaga kesehatan, rajin mencuci tangan dengan sabun, menjaga jarak jika akan beraktivitas atau bekerja, memakai masker, bahkan menetapkan aturan untuk tidak melakukan kegiatan yang melibatkan /mengumpulkan banyak orang. Anjuran untuk tinggal di rumah, bekerja dari rumah, belajar dari rumah dan beribadah dari rumah masing-masing, terus digiatkan supaya penyebaran virus segera berhenti dan berakhir. Kesejahteraan masyarakat diperhatikan dengan mengeluarkan kebijakan pergeseran anggaran pemerintah pusat sampai ke daerah, kepada hal-hal yang membantu memenuhi kebutuhan masyarakat baik dibidang kesehatan maupun sosial di masa pandemi Covid-19.

$$
\text { Wabah pandemi Covid-19 ini }
$$
merupakan bencana yang menimpa banyak sektor usaha, sehingga banyak perusahaan yang harus membuat kebijakan-kebijakan demi mempertahankan usaha dan bisnisnya. Salah satu dampak yang sangat terasa adalah kebijakan mengurangi gaji karyawan, mengurangi jam kerja sehingga mengurangi pendapatan, bahkan sampai pada tindakan memPHK-kan karyawannya. Bagi usaha kecil menengah juga tetap merasakan dampaknya, dengan menurunnya konsumen atau pelanggan yang berbelanja karena efek dari penghasilan masyarakat yang berkurang dan cenderung tidak mencukupi untuk kebutuhan pokok sehari-hari.

Masyarakat pada umumnya merasakan dampak dari wabah Pandemi Covid-19 ini, tidak terkecuali masyarakat yang ada di kelurahan sario Kota Baru khususnya lingkungan 1. Berdasarkan pengamatan yang dilakukan, masyarakat yang ada di wilayah ini sebagian besar adalah pengusaha kecil rumah tangga, yang pekerjaannya antara lain yaitu membuat kue/makanan untuk dijual di lingkungan sekolah dan kantor yang ada di kompleks rumah tempat tinggal, sopir ojek, ojek online, taxi online, usaha bengkel dan ada beberapa yang merupakan karyawan swasta yang terkena pengurangan gaji dan pengurangan jam kerja.

Perguruan tinggi sebagai salah satu agen pembangunan, dengan kegiatan tri dharma merasa ikut bertanggung jawab dalam peningkatan pengetahuan masyarakat untuk mengembangkan usaha-usaha yang dijalankan bahkan menciptakan usaha-usaha yang baru, serta pengelolaan keuangan rumah tangga di masa pandemi Covid-19 ini, sehingga bisa mendapatkan penghasilan dan meningkatkan kesajahteraan keluarga. Hal ini diwujudkan melalui kegiatan Pengabdian Kepada Masyarakat di Kelurahan Sario Kota Baru Kecamatan Sario Kota Manado sebagai tempat pelaksanaan kegiatan guna membantu 
- Ceramah/penyuluhan tentang pengembangan usaha dan strategi pemasaran

- Ceramah/Penyuluhan tentang peluangpeluang bisnis yang bisa dilakukan di rumah

\section{Tujuan dan Manfaat Kegiatan}

Untuk menyelesaikan permasalahanpermasalahan pada kelompok mitra maka telah dilaksanakan kegiatan Program Kemitraan Masyarakat (PKM) dengan tujuan dan manfaat untuk memberikan pengetahuan kepada masyarakat yang ada di keluarahan Sario Kota Baru Manado tentang bagaimana mempertahankan dan membangun ekonomi rumah tangga di masa pandemi Covid-19, bagaimana mengelola keuangan rumah tangga di masa Pandemi covid-19, bagaimana mengembangkan usaha rumahan di masa Pandemi Covid-19 serta apa saja peluangpeluang usaha baru yang dapat dilakukan di masa Pandemi Covid-19.

\section{METODE PELAKSANAAN}

\section{Sasaran kegiatan}

Sasaran yang diharapkan dari program ini adalah kelompok masyarakat yang terdampak pandemi Covid-19 yang ada di Kelurahan Sario Kota Baru khususnya lingkungan 1 dapat dan mampu mempertahankan serta membangun ekonomi rumah tangga di masa Pandemi covid19 ini sehingga kesejahteraan rumah tangga terjaga dan semakin meningkat.

\section{Lokasi kegiatan}

Kegiatan secara umum dilaksanakan di Lingkungan I Kelurahan Sario Kota Baru Kecamatan Sario Kota Manado.

\section{Metode yang digunakan :}

Metode ataupun tahap-tahap pelaksanaan kegiatan sebagai Solusi yang ditawarkan untuk menyelesaikan permasalahan pada kelompok mitra adalah peningkatan kapasitas melalui kegiatan penyuluhan dan pelatihan. Adapun beberapa pendekatan yang dilakukan dengan cara :

- Ceramah/penyuluhan tentang akuntansi sederhana dan pengelolaan kas rumah tangga
- Pembagian sembako untuk meringankan pengeluaran rumah tangga di masa pandemi covid-19

\section{HASIL DAN PEMBAHASAN}

\section{Tahap persiapan kegiatan}

Kegiatan pengabdian kepada masyarakat ini sebelum dilaksanakan maka ada beberapa persiapan-persiapan yang dilakukan oleh tim, persiapan itu berupa :

1. Menentukan waktu pelaksanaan dan jadwal pelaksanaan kegiatan pengabdian.

2. Berkoordinasi dengan pemerintah setempat dalam hal ini kepala lingkungan 1 kelurahan Sario Kotabaru.

3. Mempersiapkan materi yang akan disampaikan dalam kegiatan pengabdian ini.

4. Mempersiapkan bahan-bahan yang dapat menunjang metode pengajaran yang akan diberikan kepada para peserta.

5. Mempersiapkan bahan-bahan sembako sebagai bagian dari pengabdian mengurangi beban pengeluaran rumah tangga di masa pandemi Covid-19.

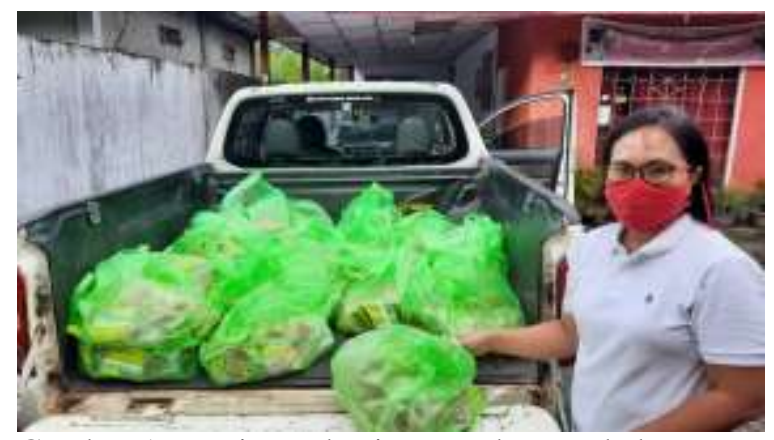

Gambar 1. Persiapan kegiatan, paket sembako yang akan di bagikan 


\section{Tahap Pelaksanaan}

Pelaksanaan kegiatan pengabdian berlangsung pada hari Sabtu, 23 Mei 2020 dimulai jam 15.00 WITA s.d 17.00 WITA dengan jumlah peserta 35 orang warga masyarakat yang ada di lingkungan 1 Kelurahan Sario Kotabaru Kecamatan Sario Kota Manado. Jumlah peserta ini merupakan perwakilan dari masing-masing kepala keluarga yang ada di lingkungan 1 dan pada umumnya terdampak dengan adanya pandemi Covid-19 saat ini. Pelaksanaan kegiatan dilakukan di ruang terbuka, yaitu di halaman rumah Keluarga TamuntuanTirayoh dengan memperhatikan protokol kesehatan yaitu semua peserta menggunakan masker, duduk sesuai kursi yang di atur dengan jarak kurang lebih dua meter dan wajib mencuci tangan sebelum duduk atau membawa hand sanitiser milik pribadi. Kegiatan dibuka dengan doa bersama yang di pimpin oleh Ibu Syamas Marta Tumangken Rimper,SE dan sambutan yang dibawakan langsung oleh kepala lingkungan 1 kelurahan Sario Kotabaru yaitu Bpk. Arnold Matialu,SH. Selanjutnya langsung dengan kegiatan pemaparan atau penyajian materi tentang Penguatan Ekonomi rumah tangga pada masa pandemi Covid-19 oleh ketua Tim pengabdian yaitu Enci Victroina Z. Tirayoh,SE.,MM.Ak. dan enci Diana Lintong,SE.,MSA.,Ak sebagai anggota. Hadir pula dalam kegiatan ini enci Dr. Jenny Morasa,SE.,MSi.,Ak sebagai dosen senior di FEB dan Dr. Gerald Tamuntuan,S.Si.,MSi.

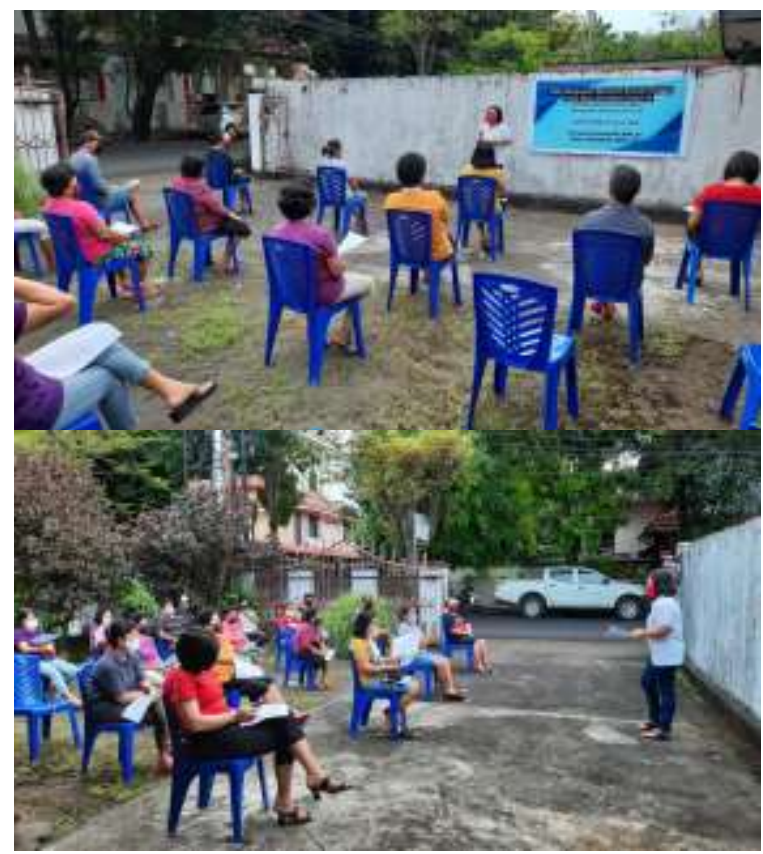

Gambar 2. Pada saat ceramah/Penyuluhan materi
Kegiatan dilanjutkan dengan sesi tanya jawab dimana semua peserta di berikan kesempatan untuk bertanya sesuai dengan materi yang telah di sampaikan. Antusias peserta sangat terlihat ketika hampir semua peserta ingin memberikan pertanyaan. Sasaran yang dipilih dalam kegiatan pengabdian ini adalah warga masyarakat yang mengalami dampak pandemi Covid-19, seperti yang telah di ungkapkan dalam latar belakang bahwa sebagian besar warga masyarakat yang ada di lingkungan satu kelurahan Sario Kotabaru adalah masyarakat yang memiliki usaha rumahan karena lingkungan tempat tinggal yang memungkinkan untuk menjalankan usaha. Dengan adanya masalah pandemi Covid-19 ini, pada umumnya masyarakat yang ada mengalami penurunan pendapatan bahkan sampai ada yang kehilangan pendapatan. Salah satu contohnya adalah ibu Sriwanti, yang menjalankan usaha kantin di sekolah. Karena pandemi sekolah di liburkan dan hanya belajar dari rumah. Otomatis kantin ibu Sriwanti di tutup, dan ibu Sriwanti tidak bisa menjual karena tidak ada pembeli/konsumen lagi. Terjadi gangguan aktivitas sosial-ekonomi yaitu kehilangan sumber pendapatan, penurunan daya beli dan kemampuan konsumsi masyarakat.

Kegiatan pengabdian ini dapat dikatakan sangat relevan dengan situasi yang dihadapi masyarakat karena memang pada prinsipnya hampir semua sektor usaha terkena dampak Covid-19 ini. Oleh sebab itu tim pengabdian membagikan pemahaman bagaimana masyarakat harus mengambil langkah bijak, mampu melihat dan memanfaatkan peluang yang ada di tengahtengah krisis yang melanda dengan membuka atau memulai usaha yang bergerak di sektor yang jelas dapat memberikan manfaat di masa ini. Sementara bagi yang sudah menjalan kan usaha yang ada seperti warung makan atau menjual kue, jasa perbengkelan di ajak untuk menyesuiakan usaha yang sementara di jalankan dengan penggunaaan media online sebagai bagian dari strategi pemasaran dan penjualan di masa sekarang. Penyesuaian ini harus dilakukan agar kita tidak akan masuk jurang kebangkrutan atau kemiskinan. Disamping itu untuk meningkatkan ekonomi rumah tangga, kita perlu melakukan pemanfaatan lahan pekarangan dengan menanam sayur-sayuran, rempah-rempah dan tanaman yang bermanfaat agar bisa mengurangi belanja rumah tangga. Selain itu juga mengatur pengeluaran/belanja rumah tangga dengan bijak yaitu dengan memprioritaskan membeli sesuatu yang merupakan kebutuhan dasar atau primer. 


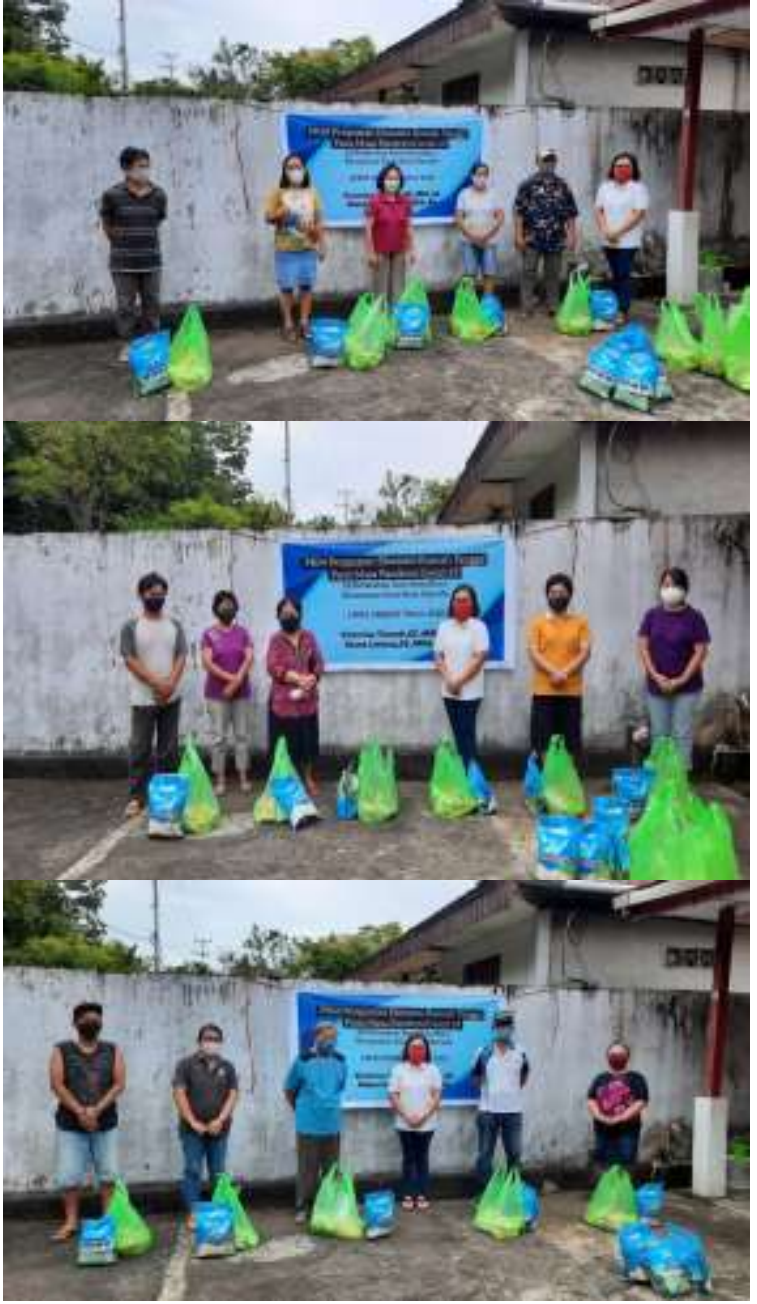

Gambar 3. Pada saat pembagian sembako

Besarnya minat dan antusiasme peserta selama kegiatan berlangsung merupakan bagian yang mendukung sehingga kegiatan pengabdian ini boleh berlangsung dengan baik. Begitu juga dengan dukungan dari pihak pemerintah dalam hal ini kepala lingkungan satu kelurahan sario Kotabaru Kecamatan Sario dan pelayan khusus kolom 5 jemaat GMIM Bethesda Ranotana Manado yang turut hadir dan mendukung kegiatan ini membuat suasana kegiatan pengabdian ini begitu kondusif dalam hal saling memberi dan menerima. Di akhir kegiatan ini, tim pengabdian membagikan paket sembako kepada semua peserta yang hadir sebagia bentuk pengabdian dalam mengurangi beban belanja rumah tangga di masa pandemi Covid-19.

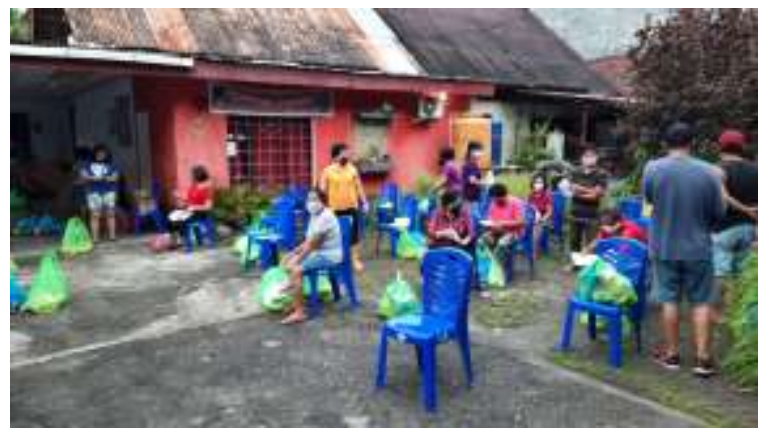

Gambar 4. Suasana pada saat kegiatan

Kegiatan pengabdian ini juga dilanjutkan pada minggu berikutnya yakni hari Sabtu, 30 Mei 2020 dengan membagikan paket sayur mayur dan daging kepada masyarakat, sebagai peserta kegiatan PKM ini.

\section{KESIMPULAN DAN SARAN}

Program Kemitraan Masyarakat (PKM) untuk memberikan penguatan ekonomi rumah tangga di masa pandemi covid-19 di Kelurahan Sario Kota Baru Kecamatan Sario Kota Manado telah dilakukan dalam bentuk ceramah /penyuluhan serta membantu masyarakat meringankan biaya rumah tangga di masa pandemi covid-19 dengan membagikan bahan sembako.

\section{UCAPAN TERIMA KASIH}

Terima kasih diucapkan kepada Pemerintah Kelurahan Sario Kota Baru dalam hal ini Kepala lingkungan 1, serta masyarakat yang hadir mengikuti kegiatan ini, juga kepada pelayan khusus setempat GMIM Bethesda Ranotana Manado atas dukungan dan kerjasamanya dalam kegiatan PKM. Ucapan terima kasih juga disampaikan kepada LPPM Unsrat yang telah membiayai kegiatan pengabdian ini melalui skim Program Kemitraan Masyarakat (PKM) tahun 2020. 


\section{DAFTAR PUSTAKA}

Abdul, Rosia. 2007. Manajemen Usaha Kecil, Menengah dan Koperasi. Pusat Pengembangan Bahan Ajar. UMB.

Bayumedia. Marsum. 2001. Restoran dan Segala Permasalahannya. Yogyakarta: Penerbit Andi Ratminto dan Atik Winarsih. 2005.

Kasmir, 2010. Kewirausahaan,PT Raja Grafindo Persada

Robert Libby, Patricia A.Libby, Daniel G.Short. 2007. Akuntansi Keuangan. Yogyakarta: Penerbit Andi, Edisi kelima.

Wibowo \& Abubakar A, 2008. Akuntansi Keuangan Dasar 1. Edisi Ketiga. Cikal Sakti. Grasindo. Jakarta.

http://ilmuakuntansi.web.id/pengertianakuntansi-fungsi-dan-bidang-akuntansi//

https://www.habibiecenter.or.id/img/publicatio n/09da4f0fd333100e97d2b2bc1aec3163.pdf 